\title{
Acute Pancreatitis Induced by Compression of Main Pancreatic Duct due to Large Stones and Catheter in the Common Bile Duct
}

\author{
Young Min Choi, Seung Uk Jeong, Hwa Young Lee, Hoe Soo Jang, Eun Kwang Choi \\ Department of Internal Medicine, Jeju National University School of Medicine, Jeju, Korea
}

Acute pancreatitis is occasionally caused by endoscopic treatments or radiologic interventions of the pancreatobiliary tract. However, no reports indicate that acute pancreatitis resulted from the insertion of a percutaneous transhepatic cholangiography (PTCS) catheter in the common bile duct (CBD). A 65-year-old woman visited our hospital with acute cholangitis due to about $3 \mathrm{~cm}$-sized CBD stones. We planned to perform PTCS because of the large stones and altered anatomy (Billroth II). The patient was discharged after tract dilatation and insertion of a PTCS catheter in the distal CBD without manipulations of Ampulla of Vater (AOV). However, she visited the emergency room due to acute pancreatitis at three days after discharge. Computed tomography revealed upstream dilation of the main pancreatic duct following the compressed area of a large stone and catheter. Thus, we report a case that presented with acute pancreatitis induced by insertion of a PTCS catheter without manipulations of AOV.

Keywords: Catheter, Common bile duct, Stone, Pancreatitis

\author{
Received Nov. 17, 2016 \\ Revised Dec. 30, 2016 \\ Accepted Jan. 2, 2017
}

Corresponding author : Seung Uk Jeong

Department of Internal Medicine, Jeju National University School of Medicine, 15 Aran 13-gil, Jeju 63241 , Korea

Tel. +82-64-754-8108 Fax. +82-64-717-1131

E-mail; suhmok@jejunu.ac.kr

\section{INTRODUCTION}

Acute pancreatitis is caused by various etiologies, although the pathogenic mechanisms are not fully understood. ${ }^{1}$ The causes of acute pancreatitis are broadly categorized as obstruction, toxin, trauma, metabolic abnormalities, and infection. Iatrogenic pancreatitis occasionally develops from endoscopic retrograde cholangiopancreatography (ERCP), endoscopic sphincterotomy, or manometry of sphincter of Oddi. ${ }^{2-7}$ However, acute pancreatitis after the insertion of a percutaneous transhepatic cholangiography (PTCS) catheter has not been previously reported. Hence, we report a case that presented with acute pancreatitis resulting from the obstruction of the main pancreatic duct due to compression by a stiff catheter and large stones in the common bile duct (CBD) following the insertion of a PTCS catheter. 

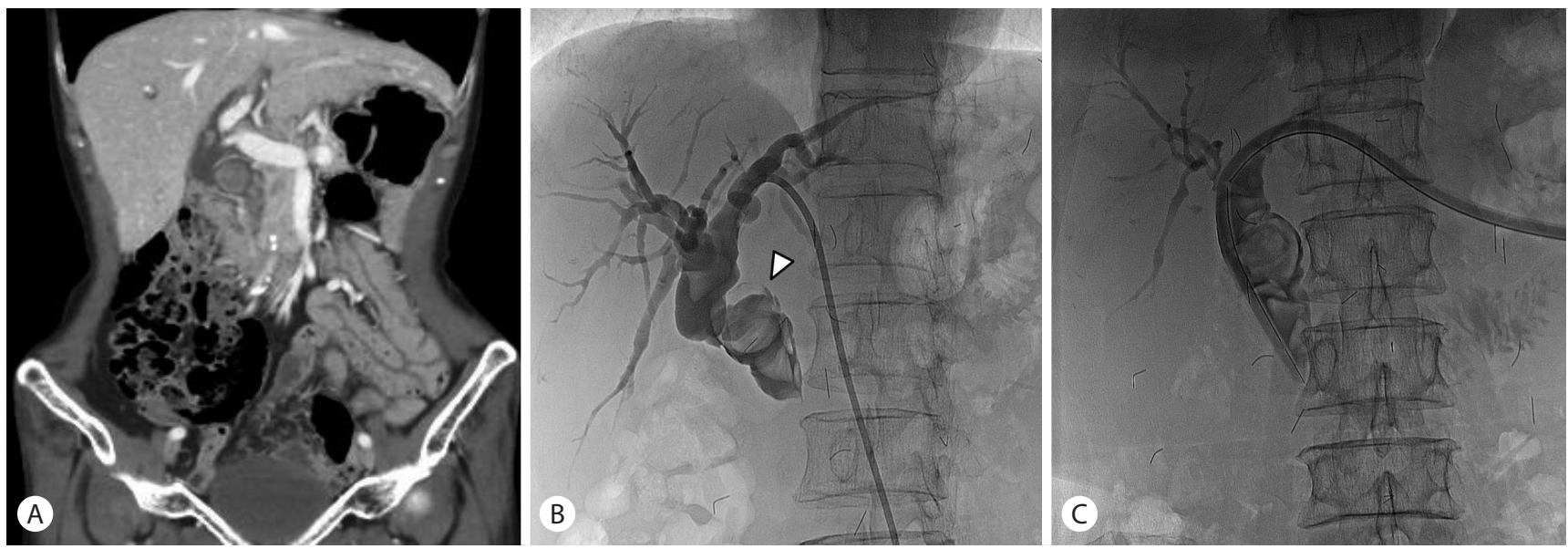

Fig. 1. Consecutive evaluations of common bile duct (CBD) and large CBD stones. (A) An axial view of abdominal computed tomography showed multiple large stones in tortuous CBD. (B) Percutaneous transhepatic cholangiography showed multiple large filling defects inside CBD. The largest filling defect was measured $3 \mathrm{~cm}$ in diameter (arrow head). (C) After insertion of a percutaneous transhepatic cholangioscopy catheter, CBD was straightened and the filling defects were pushed to the medial side of CBD.

\section{CASE}

A 65-year-old woman presented with postprandial epigastric pain that lasted for several days. Twenty years ago, the patient had undergone a subtotal gastrectomy with Billroth II for gastric ulcer and a cholecystectomy. Vital signs were stable. Tenderness of the epigastrium and right upper quadrant of the abdomen were observed in the physical examination. Results of laboratory examinations showed that white blood cell count was $4,050 / \mathrm{mm}^{3}$, aspartate transaminase was $1,035 \mathrm{IU} / \mathrm{L}$, alanine transaminase was $824 \mathrm{IU} / \mathrm{L}$, total bilirubin was $2.4 \mathrm{mg} /$ $\mathrm{dL}$, alkaline phosphatase was $1,343 \mathrm{U} / \mathrm{L}$, and gamma-glutamyl transpeptidase was $342 \mathrm{U} / \mathrm{L}$. Abdominopelvic computed tomography (CT) exhibited multiple large stones in the dilated CBD and left intrahepatic duct (Fig. 1A). The size of the largest CBD stone was about $3 \mathrm{~cm}$. The patient was diagnosed with acute cholangitis due to multiple CBD stones. Antibiotics and stone removal were considered to treat the cholangitis. Percutaneous transhepatic biliary drainage (PTBD) was planned to resolve the biliary obstruction because of altered anatomy after subtotal gastrectomy with Billroth II anastomosis. A PTBD (8.5 French $[\mathrm{Fr}])$ catheter was inserted through the left intrahepatic duct (Fig. 1B). PTBD catheter (Sung Won Medical Co., Ltd, Cheongju, Korea) is made from polyurethane. After one week, the PTBD tract was dilated using a 14-

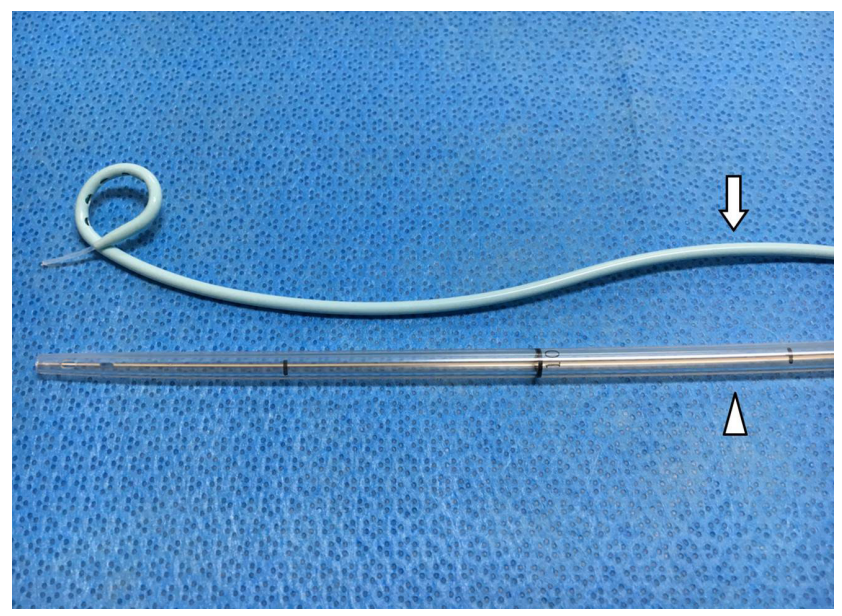

Fig. 2. Comparison between percutaneous transhepatic biliary drainage (PTBD) catheter (arrow) with percutaneous transhepatic cholangioscopy (PTCS) catheter (arrow head). PTBD catheter (polyurethane) is thin and flexible. PTCS catheter (polyvinyl) is naturally hard and less pliable. PTCS catheter has larger diameter (18 Fr) than PTBD catheter (8.5 Fr). PTCS catheter is stiffer and harder than PTBD catheter.

18 Fr dilator (Cook Medical, Bloomington, USA) in sequence. The tip of the 18 Fr PTCS catheter was located in the distal CBD across the large CBD stones. PTCS catheter (Akita Sumitomo Bakelite Co. Ltd, Dongguan, Japan) is made from polyvinyl chloride (Fig. 2). After insertion of the PTCS catheter, the $\mathrm{CBD}$ was straightened and the large stone was pushed to the medial side of CBD (Fig. 1C). The patient was discharged after tract dilatation, and PTCS was scheduled for two weeks 
later. However, the patient visited the emergency room for severe abdominal pain three days after discharge. Vital signs were stable. Laboratory examinations were as follow: aspartate transaminase $40 \mathrm{IU} / \mathrm{L}$, alanine transaminase $41 \mathrm{IU} / \mathrm{L}$, gammaglutamyl transpeptidase $156 \mathrm{IU} / \mathrm{L}$, total bilirubin $0.5 \mathrm{mg} / \mathrm{dL}$, amylase 3,394 IU/L, and lipase 2,965 IU/L. Abdominopelvic CT demonstrated diffuse swelling of the pancreatic head, dilated main pancreatic duct, and peripancreatic infiltration. A small amount of fluid collection was also observed in the anterior of pararenal space. Large CBD stones were located at the medial side of the pancreatic head and a PTCS catheter was inserted at the lateral side of the pancreas. Due to abdominal pain, elevated pancreatic enzymes, and radiologic abnormalities, the patient was diagnosed with acute pancreatitis. However, the main pancreatic duct showed slight dilatation on the CT scan, before insertion of a PTCS catheter (Fig. 3A). We confirmed that a huge stone was pushed to the pancreas by the stiff PTCS catheter, and the main pancreatic duct was dilated definitely following the compressed site formed by the stone (Fig. 3B). Other causes of acute pancreatitis, such as alcohol, drugs, and metabolic abnormalities, were excluded. Therefore, the cause of acute pancreatitis was attributed to the obstruction of the pancreatic duct after the insertion of the PTCS catheter which did not pass through the Ampulla of Vater (AOV). The catheter was repositioned about $3 \mathrm{~cm}$ back in order to resolve the compression of the main pancreatic duct. Abdominal pain and blood tests were improved after withdrawal of the PTCS catheter and conservative treatment.
Follow-up CT revealed improvement of the dilation of the main pancreatic duct after one week (Fig. 3C). After confirming the improvement of the pancreatitis, PTCS was performed. All CBD stones were removed during two sessions of PTCS. Although balloon dilations of AOV and the reinsertion of the PTCS catheter in the distal CBD were performed, there was no recurrence of acute pancreatitis.

\section{DISCUSSION}

Acute pancreatitis is defined as acute and sudden inflammation of the pancreas. It is caused by various etiologies including gallstone, alcohol, hypertriglyceridemia, and anatomic abnormalities. ${ }^{2}$ Moreover, iatrogenic pancreatitis can be caused by traumas induced by ERCP, endoscopic sphincterotomy, manometry, or surgery. PTCS is done in order to promote biliary drainage and to remove intrahepatic and CBD stones by using a flexible choledochoscope. PTCS is performed after insertion of a PTBD catheter and serial dilatation of the percutaneous transhepatic tract. PTCS has been associated with rare complications of the pancreatic system, if it does not perform the manipulations of AOV. In particular, there has been no report about acute pancreatitis following the insertion of a PTCS catheter. However, some cases of acute pancreatitis related percutaneous transhepatic biliary intervention have been reported. ${ }^{8-11}$ In these reports, acute pancreatitis developed only in cases with stent or catheter insertion across the AOV. There was no acute pancreatitis
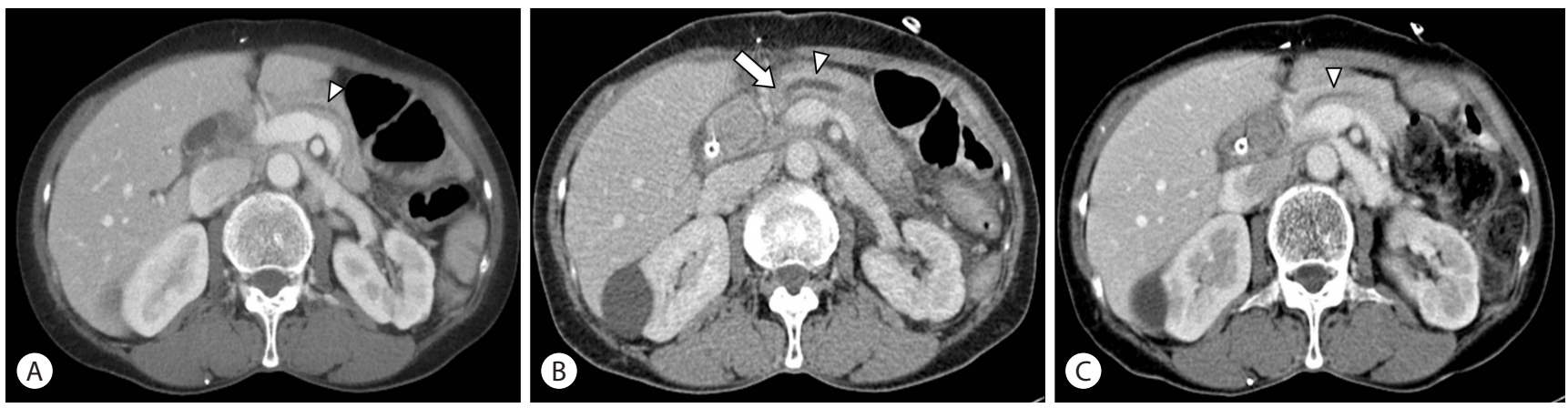

Fig. 3. Sequential changes of the main pancreatic duct morphology on coronal view of abdominal computed tomography. (A) Before insertion of a percutaneous transhepatic cholangioscopy (PTCS) catheter, the main pancreatic duct showed slight dilatation (arrow head). (B) After insertion of the PTCS catheter, the main pancreatic duct showed definite upstream dilatation (arrow head) following the compressed area (arrow). (C) After reposition of the PTCS catheter, the main pancreatic duct was decompressed (arrow head). 
without manipulation of AOV. It has been generally accepted that injury of AOV by mechanical stimulation and the obstruction of pancreatic duct by the inserted catheter or stent are the causes of acute pancreatitis.

In our patient, there was no cause for acute pancreatitis, such as alcohol, drugs, or metabolic abnormalities, except for PTCS catheter insertion. The PTCS catheter and large CBD stones were impacted in the narrow CBD and pressed the pancreatic head portion, although the catheter was not placed across the AOV. It suggests that PTCS catheter may have the own space in the narrow $\mathrm{CBD}$ and may shift the expansile force toward the pancreas than soft PTBD catheter. As a result, the stiff PTCS catheter and huge stones make a force toward the pancreatic head portion, which may raise obstruction of the main pancreatic duct following the compressed site. Actually, the definite upstream dilation of the main pancreatic duct was observed following the compressed area of the large CBD stone which was pushed by PTCS catheter. In order to resolve the pressure of the main pancreatic duct, the catheter was repositioned back about $3 \mathrm{~cm}$. The compressed site of the CBD stone and catheter may be changed after withdrawal of the catheter, and the pressure of the main pancreatic duct was decreased. Acute pancreatitis was improved because of decompression of the pancreatic duct and conventional therapy. Moreover, there was not another event of acute pancreatitis, though manipulations of $\mathrm{AOV}$ and reinsertion of the PTCS catheter during two sessions of PTCS. For these reasons, acute pancreatitis of this patient was regarded as a complication that was induced by the compression of the main pancreatic duct by the catheter and large stones in the CBD. There was no report associated with catheter induced pancreatitis that was not associated with manipulation of AOV, although cases of acute pancreatitis due to distal biliary manipulation such as stent and catheter across the ampulla have been reported. However, we ascertain that acute pancreatitis can be caused by compressing the main pancreatic duct when an instrumental device is inserted within the narrow space of CBD. Therefore, diagnosis of acute pancreatitis should be attempted when the patient has new or worsened abdominal pain after the insertion of the instrument in $\mathrm{CBD} .^{12}$
In conclusion, we suggest that an inserted instrument, such as a PTCS catheter, should be considered as a probable cause of acute pancreatitis, as the catheter and stones can obstruct the pancreatic duct. Further studies will be required to determine the prevalence and risk factors. Owing to the potential for fatal clinical deterioration, clinicians should be alert to the possibility of acute pancreatitis.

\section{요 약}

급성 췌장염은 다양한 원인에 의해 발생되는 췌장의 염증 성 질환으로 담도질환에 대한 내시경 시술이나 영상의학적 시술에 의해서 유발되기도 한다. 담도 시술과 관련하여 발생 하는 췌장염은 담도에 대한 조작보다는 바터팽대부를 절개 또는 확장시키거나 바터팽대부를 통과시켜 스텐트 혹은 도 관을 거치하면서 유발되는 췌관의 압박에 의해 발생하는 것 으로 알려져 있다. 바터팽대부에 대한 조작을 시행하지 않는 경우에는 췌장염 발생의 위험성이 없는 것으로 되어 있고 더 하여 경피경관담도경 시술을 위한 도관 삽입 후에 췌장염이 발생한 경우는 보고된 바가 없었다. 본 증례에서는 $3 \mathrm{~cm}$ 가 량의 거대 총담관 담석들에 의해 발생된 담도염에 대해 경피 경관담도경 시술을 준비하는 과정 중 총담관에 도관을 삽입 한 이후 급성 췌장염이 발생하였다. 이에 저자들은 원위부 총담관 내부에 삽입된 도관으로 인해 거대 총담관 담석이 췌 장두부를 압박하였고 이로 인한 주췌관의 가역적인 폐색이 유발되어 급성 췌장염이 발병한 증례를 경험하였기에 문헌 고찰과 함께 보고하는 바이다.

국문 색인: 췌장염, 총담관, 담석, 카테터

\section{Conflicts of Interest}

The author has no conflicts to disclose.

\section{REFERENCES}

1. Do JH. Mechanism of severe acute pancreatitis: focusing on development and progression. Korean J Pancreas Biliary Tract 2015;20:115-123.

2. Whitcomb DC. Clinical practice. Acute pancreatitis. N Engl J Med 2006;354:2142-2150.

3. Loperfido S, Angelini G, Benedetti G, et al. Major early complications from diagnostic and therapeutic ERCP: a prospective multicenter study. 
Gastrointest Endosc 1998:48:1-10.

4. Freeman ML, DiSario JA, Nelson DB, et al. Risk factors for post-ERCP pancreatitis: a prospective, multicenter study. Gastrointest Endosc 2001;54:425-434.

5. Thomas PR, Sengupta S. Prediction of pancreatitis following endoscopic retrograde cholangiopancreatography by the 4-h post procedure amylase level. J Gastroenterol Hepatol 2001;16:923-926.

6. Friedland S, Soetikno RM, Vandervoort J, Montes H, Tham T, CarrLocke DL. Bedside scoring system to predict the risk of developing pancreatitis following ERCP. Endoscopy 2002;34:483-488.

7. Yaghoobi M, Pauls Q, Durkalski V, et al. Incidence and predictors of post-ERCP pancreatitis in patients with suspected sphincter of Oddi dysfunction undergoing biliary or dual sphincterotomy: results from the EPISOD prospective multicenter randomized sham-controlled study. Endoscopy 2015;47:884-890.

8. Al-Bahrani AZ, Holt A, Hamade AM, et al. Acute pancreatitis: an under- recognized risk of percutaneous transhepatic distal biliary intervention. HPB (Oxford) 2006;8:446-450.

9. Jeong $Y W$, Shin KD, Kim SH, et al. The safety assessment of percutaneous transhepatic transpapillary stent insertion in malignant obstructive jaundice: regarding the risk of pancreatitis and the effect of preliminary endoscopic sphincterotomy. Korean J Gastroenterol 2009;54:390-394.

10. Knyrim K, Wagner HJ, Pausch J, Vakil N. A prospective, randomized, controlled trial of metal stents for malignant obstruction of the common bile duct. Endoscopy 1993;25:207-212.

11. Inal $M$, Akgül $E$, Aksungur $E$, Demiryürek $H$, Yağmur O. Percutaneous self-expandable uncovered metallic stents in malignant biliary obstruction. Complications, follow-up and reintervention in 154 patients. Acta Radiol 2003:44:139-146.

12. Testoni PA, Bagnolo F, Caporuscio S, Lella F. Serum amylase measured four hours after endoscopic sphincterotomy is a reliable predictor of postprocedure pancreatitis. Am J Gastroenterol 1999;94:1235-1241. 